\title{
PENDUGAAN DAERAH POTENSIAL PENANGKAPAN IKAN LAYANG (Decapterus sp) BERDASARKAN SPL DAN KLOROFIL-A DI PERAIRAN PESISIR PULAU TERNATE
}

\author{
Fajrin S. Laitupa*, Sahril Kacoa*, M. Askar Laitupa*, Umar Tangke** \\ *Alumni dan Mahasiswa THP FAPERTA UMMU-Ternate, Email: : \\ **Staf Pengajar Prodi THP FAPERTA UMMU-Ternate, Email: khakafart@yahoo.com
}

\begin{abstract}
ABSTRAK
Potensi perikanan pelagis kota Ternate lebih didominasi oleh pelagis kecil diantaranya jenis ikan layang, ikan komo dan ikan selar. Ikan layang adalah jenis ikan yang sangat potensial dikembangkan, hal ini terlihat dengan jumlah produksi ikan layang mendekati $980.000 \mathrm{~kg} /$ tahun. Jumlah produksi ini masih dibawah MSY atau pemanfaatannya baru sekitar 30 \% dari MSY. Upaya untuk optimalisasi sumberdaya yang selalu terus dilakukan diantaranya dengan peningkatan jumlah unit penenagkapan serta peningkatan informasi mengenai daerah penangkapan. Salah satu cara yang dapat dilakukan untuk dapat mengoptimalisasi sumberdaya ikan pelagis tersebut adalah dengan menduga daerah penangkapan ikan dengan menggunakan data citra satelit oleh sebab itu penelitian ini bertujuan untuk mengetahui hubungan antara suhu permukaan laut dan klorofil-a terhadap hasil tangkapan ikan layang, kemudian dipetakan dalam peta prediksi daerah penangkapan ikan layang di perairan pesisir pulau Ternate. Hasil penelitian menunjukan bahwa Secara bersama-sama suhu permukaan laut dan klorofil-a berpengaruh nyata terhadap hasil tangkapan ikan di pesisir pulau Ternate, sedangan hasil uji $t$ menunjukan bahwa secara individu parameter klorofil-a yang berpengaruh nyata terhadap hasil tangkapan ikan laying (Decapterus sp), dengan prediksi daerah penangkapan yang potensial penangkapan ikan laying di perairan laut pulau Ternate terdapat pada bagian timur pulau ternate dengan koordinat 0'50'14.0" N, 127025'15" E.
\end{abstract}

Kata Kunci: Decapterus sp, Layang, SIG

\section{PENDAHULUAN}

\subsection{Latar Belakang}

Upaya untuk optimalisasi pemanfaatan sumberdaya perikanan khususnya ikan pelagiskecil selalu terus dilakukan, diantaranya peningkatan unit penangkapan serta peningkatan informasi mengenai kondisi oseanografi yang berkaitan erat dengan daerah potensial penangkapan ikan tersebut (Laevastu dan Hayes, 1981; Reddy,1993).Saat ini, khususnya untuk nelayan tradisional, armada penangkap ikan berangkat dari fishing base ke fishing ground bukan untuk menangkap ikan secara langsung tetapi untuk mencari posisi yang strategis untuk melakukan penangkapan ikan. Akibatnya, operasi penangkapan ikan yang dilakukan selalu berada dalam ketidakpastian tentang daerah yang potensial untuk penangkapan ikan dan berujung pada fluktuasi hasil tangkapan. Kondisi seperti ini tentunya tidak menguntungkan dalam upaya pemanfaatan sumberdaya perikanan secara optimum dan berkelanjutan.

Tingginya potensi sumberdaya perikanan Indonesia didukung oleh letak geografis Indonesia yang memiliki karakteristik yang unik yaitu sebagai jalur perlintasan massa air dari samudra Pasifik menuju samudra Hindia (Gordon dan Fine, 1996), sehingga dapat diperkirakan banyak 
terdapat daerah gerombolan dengan diversitas yang tinggi.

Potensi perikanan pelagis kota Ternate lebih didominasi oleh pelagis kecil diantaranya jenis ikan layang, ikan komo dan ikan selar. Ikan layang adalah jenis ikan yang sangat potensial dikembangkan, hal ini terlihat dengan jumlah produksi ikan layang mendekati $980.000 \mathrm{~kg} / \mathrm{tahun}$.Jumlah produksi ini masih dibawah MSY atau pemanfaatannya baru sekitar $30 \%$ dari MSY (DKP Kota Ternate, 2011). Untuk meningkatkan jumlah produksisampai mendekati MSY maka berbagai hal perlu di lakukan diantaranya penentuan daerah penangkapan yang lebih potensial.

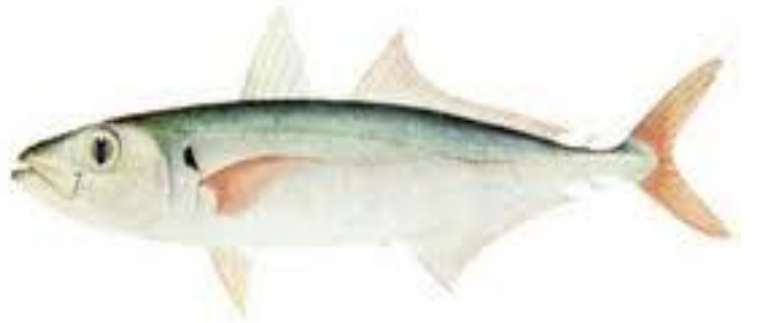

Gambar 1. Ikan Layang (Decapterus $s p$ )

Keberadaan daerah penangkapan ikan umumnya bersifat dinamis, sehingga pola distribusinya akan selalu mengikuti kondisi perairan yang sesuai untuk kehidupan dan pertumbuhannya. Habitat ikan umumnya dipengaruhi oleh parameter oseanografi seperti suhu permukaan laut dan konsentrasi klorofil-a (Laevastu and Hayes, 1981; Gunarso, 1985). Untuk memahamidinamika lingkunganlaut,termasukmengetahuiperubaha nketersediaan sumberdaya ikan dan daerah potential penangkapannya, saat ini telah dikembangkan teknologi penginderaan jauh dengan satelit (satellite remote sensing) untuk bidang perikanandengan maksud untuk membantu menyediakan database pada berbagaimacam peruntukkan dalam bidang oseanografiperikanan misalnya untuk prediksi kandidat fishingground(Zainuddin et al, 2007).

Proses penentuan daerah potensial penangkapan ikan laying dilakukan dengan menganalisis jumlah hasil tangkapan dengan parameter oseanografi yang didapat melalui pengukuran in situ dan menggunakan data citra satelit Aqua/MODIS. Penggunaan data citra satelit dilakukan melalui beberapa tahap yaitu pengolahan data awal yang dimulai dari pemotongan daerah studi berdasarkan zonasi dan konversi data MODIS menjadi format data yang dapat dibaca dalam sistem informasi geografis. Data yang sudah diolah merupakan data yang telah terkoreksi geometrik secara sistematik. Koreksi geometrik yang dilakukan menggunakan teknik set draw point dengan mengambil satu titik kontrol (kenampakan yang sama) sebagai titik acuan pada titik pada citra dan peta dasar acuan.

Data satelit sangat bermanfaat khususnya untuk mengkaji daerah potensial yang relatif luas dengan cepat. Hasil analisis dengan teknik statistik terhadap kedua data tersebut kemudian dapat divisualisasikan dengan sistematis dan rinci dalam bentuk peta thematik yang dibangun dengan teknik sistem informasi geografis. Dengan demikian berbagai informasi yang diintegrasikan dalam peta thematic diharapkan sangat membantu nelayan dalam menemukan daerah potensial untuk menangkap Ikan layang.

\subsection{Tujuan dan Manfaat Penelitian}

Penelitian ini bertujuan untuk mengetahui hubungan antara suhu permukaan laut dan klorofil-a terhadap hasil tangkapan ikan layang, kemudian dipetakan dalam peta prediksi daerah penangkapan ikan layang di perairan pesisir pulau Ternate.

Hasil penelitian ini diharapkan dapat dijadikan sebagai informasi dan bahan kajian dalam pengembangan dan pengelolaan potensi ikan layang di Indonesia, khususnya di perairan pesisir pulau Ternate.

\section{METODE PENELITIAN}

\subsection{Waktu dan Tempat}

Penelitian ini direncanakan untuk dilaksanakan pada bulan Maret- Mei 2015 bertempat di perairan Pulau Ternate.

\subsection{Alat dan Bahan}

Peralatan yang digunakan dalam penelitian ini antara lain :

1. Perangkat keras (Hardware)

1 unit Komputer dengan spesifikasi terbaik untuk mengolah gambar 


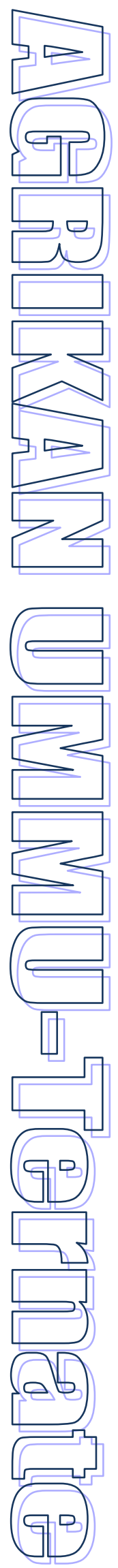

2. Perangkat Lunak (Software)

a. Sistem Operasi Windows 2003 dan 2010

b. ER Mapper 6.4

c. ENVI 4.0

d. Microsoft Word 2003

3. GPS

4. Termometer

5. Fishfinder

6. Kamera digital

Bahan yang digunakan dalam penelitian ini adalah :

1. Citra satelit NOAA-AVHRR bulan Maret sampai Mei 2015.

2. Peta topografi Indonesia skala 1:1.000.000 Bakosurtanal (peta digital) sebagai acuan koreksi geometrik.

\subsection{MetodeKerja}

Tahapan yang akan dilaksanakan dalam kegiatan penelitian ini adalah seperti pada diagram alur pada Gambar 1.

Berikut adalah penjelasan diagram alur :

1. Tahap Identifikasi dan Perumusan Masalah Tahap awal sebelum memulai penelitian adalah merumuskan masalah yaitu menentukan masalah apa yang timbul dan harus dipecahkan melalui penelitian ini, penetapan batas, penentuan tujuan dari penelitian dan manfaat uang diperoleh.

2. Tahap Studi Literatur

Dalam tahap ini mempelajari secara mendalam tentang arti dan konsep penginderaan jauh terutama aplikasinya pada suhu permukaan laut dan persebaran klorofil serta panduan untuk pembuatan web.

3 Tahap Pengumpulan data

- Data spasial

Dataspasial adalah data yang mempunyai referensi geografis (sistem koordinat) yang mengacu bumi (georeference). Data spasial yang dikumpulkan untuk mendukung penelitian ini adalah:

a. Citra satelit NOAA-AVHRR bulan Maret - Mei 2015.

b. Peta topografi Indonesia skala 1:1.000.000 Bakosurtanal (peta digital) sebagai acuan koreksi geometrik.

4. Tahap Pengolahan data

- Koreksi Geometrik
Proses koreksi geometrik citra dilakukan untuk menghilangkan kesalahan spasial citra yang disebabkan oleh beberapa faktor pada saat perekaman oleh sensor satelit. Koreksi geometrik dilakukan sesuai dengan jenis atau penyebab kesalahannya, yaitu kesalahan sistematik dan kesalahan random. Koreksi radimetrik mempunyai tiga tujuan, yaitu (1) melakukan rektifikasi (pembetulan) atau restorasi (pemulihan) citra agar koordinat citra sesuai dengan koordinat geografi;(2) registrasi (mencocokkan) posisi citra dengan citra lain atau mentransformasikan sistem koordinat citra multispektral atau citra multitemporal; (3) registrasi citra ke peta atau transformasi sistem koordinat citra ke peta, yang menghasilkan citra dengan sistem proyeksi tertentu.

- Algoritma Mc Millin \& Crosby Untuk Menentukan Suhu Permukaan Laut

Algoritma McMillin \& Crosby:

$S P L=T b 4+2,702 \times(T b 4-T b 5)-0,582$ (3.6)

Dimana :

$$
\begin{aligned}
& \text { SPL }=\text { Suhu Permukaan Laut } \\
& \text { Tb4 }=\text { Thermal band } 4 \\
& \text { Tb5 }=\text { Thermal band } 5
\end{aligned}
$$

5. Tahap Analisa

- Analisa kesalahan geometrik.

- Analisa SPL, Daerah Upwellingdan Daerah Front Thermal dari data yang telah didapatkan.

- Analisis Regresi

6. Tahap Hasil

- Hasil yang di peroleh dari penelitian ini berupa peta predikasi daerah tangkapan ikan.

\section{HASIL DAN PEMBAHASAN}

3.1. Aspek Perikanan Layang di Perairan Pesisir Pulau Ternate

Ikan layang (Decapterus sp) merupakan jenis ikan ekonomis penting yang umumnya ditangkap dengan menggunakan alat tangkap pancing, gill net dan purse seine (pejeko) dan alat bantu penangkapan rumpon serta lampu dengan tujuan untuk mengkonsentrasikan ikan pada satu area. 
Musim penangkapan ikan layang (Decapterus sp) dilakukan sepanjang tahun dengan area yang berpindah-pindah sesuai dengan pola dsitribusi ikan layang (Decapterus sp) menurut bulan dan musim. Total produksi ikan layang (Decapterus sp) salama bulan Maret sampai Mei diperaian pesisir pulau Ternate adalah sebesar $4.593 \mathrm{~kg}$, dengan sebaran produksi pada masing-masing bulan selama musim peralihan I dapat dilihat pada Gambar 2.

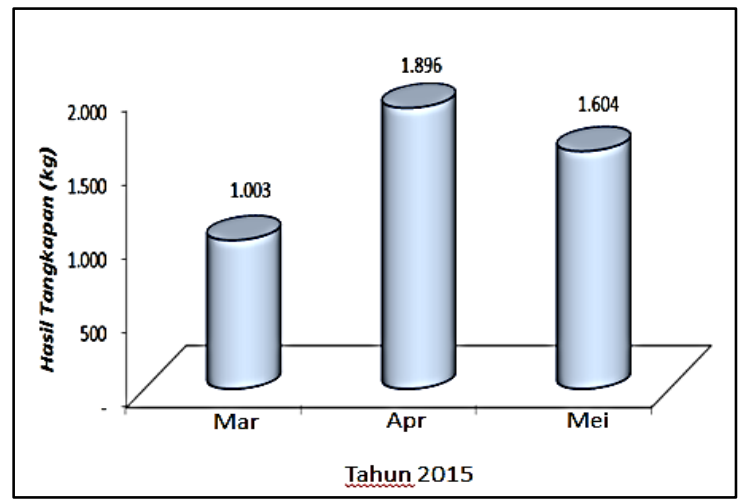

Gambar 2. Produksi Ikan Layang (Decapterus sp)

\subsection{Analisis Hubungan Parameter}

Oseanografi dan Hasil Tangkapan Ikan Layang (Decapterus sp)

Keberadaan sumberdaya perikanan pada suatu perairan sangat dipengaruhi oleh parameter oseanografi. Analisis hubungan parameter oseanografi dan hasil tangkapan dilakukan untuk melihat hubungan antara faktor oseanorafi dan hasil tangkapan sehingga dapat diprediksi distribusi daerah penangkapan potensial selama bulan Maret sampai Mei 2015. Analisis hubungan parameter oseanografi dengan menggunakan regresi berganda dengan variabel dependent adalah hasil tangkapan ikan layang $(Y)$ dan variabel independent adalah suhu pemukaan laut $\left(X_{1}\right)$ dan klorofil-a $\left(\mathrm{X}_{2}\right)$. Hasil analisis regresi berganda adalah adalah :

a) Uji normalitas data, hasil uji normalitas dapat dilihat bahwa setelah data di logaritmakan maka semua data berditsribusi normal, dimana ini dilihat dari nilai signifikansi yang kecil dari 0,1 yaitu 0,001 .

b) Uji multikolinieritas, hasil uji multikolinieritas menunjukan bawha nilai variabel independent tidak terjadi masalah kolinieritas karena nilai VIF kurang dari 10.

Uji F (analisis varians), hasil uji F menunjukan dilihat bahwa nilai $F$ hitung adalah 49.602 dengan nilai signifikansi 0.000 ( $<.1)$, ini berarti bahwa secara bersama-sama faktor SPL dan klorofil-a berpengaruh terhadap hasil tangkapan ikan layang (Decapterus sp). Dengan model yang terbentuk adalah $\log Y=\log 8.011-$ $4.432 \log b_{1}-2.382 \log b_{2}$, dimana $b_{1}$ adalah SPL dan $b_{2}$ adalah Klorofil-a. Hasil uji F dapat dilihat pada Tabel 1.

Model tersebut selanjutnya digunakan untuk meramalkan distribusi ikan Layang (Decapterus sp). Hubungan yang terbentuk antara hasil tangkapan lapangan dengan hasil tangkapan prediksi dapat dilihat pada Gambar 3.

d. Koefisien determinasi, nilai koefisien adalah sebesar 0.88 . artinya $88.0 \%$ hasil tangkapan disebabkan oleh SPL dan klorofil-a sedangkan $22 \%$ hasil tangkapan dipengaruhi oleh faktor lain. Faktor lain yang diduga mempengaruhi distribusi hasil tangkapan adalah salinitas, dimana diketahui bahwa daerah penangkapan yang berdekatan dengan daratan sehingga dengan masuknya air tawar selain mempengaruhi sebaran SPL dan klorofil-a juga mempengaruhi kadar garam (salinitas), hal ini sesuai dengan hasil penelitian Zainuddin (2007) bahwa hasil tangkapan ikan Layang didaerah Bantaeng 


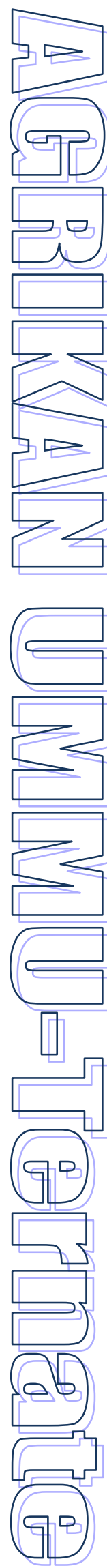

(Sulewesi Selatan) berskisar antara 33 - 35 \%.

e. Uji $t$, hasil uji menunjukan bahwa secara individu perubahan klorofil-a akan sangat mempengaruhi distribusi ikan layang diperairan pesisir Ternate, sedangankan parameter SPL tidak mempengaruhi distribusi ikan Layang (Decapterus sp) perairan pesisir laut Ternate. Hal ini dapat lihat dengan nilai signifikansi pada Tabel 2 dimana nilai signifikansi untuk suhu permukaan laut (SPL) adalah $0.645(>0.1)$ dan nilai signifikansi klorofil-a adalah $0.000(<0.1)$.

Tabel 1. Hasil Uji F Paramater Oseanografi dan Hasil Tangkapan Ikan Layang (Decapterus sp)

\begin{tabular}{cccccc}
\multicolumn{1}{c}{ Mode } & $\begin{array}{c}\text { Su } \\
1\end{array}$ & Df & $\begin{array}{c}\text { Mean } \\
\text { Square }\end{array}$ & F & Si \\
\hline Regresion & 0.322 & 2 & 0.161 & 49.602 & 0.000 \\
Residual & 0.88 & 31 & 0.003 & & \\
Total & 0.049 & 33 & & & \\
\hline
\end{tabular}

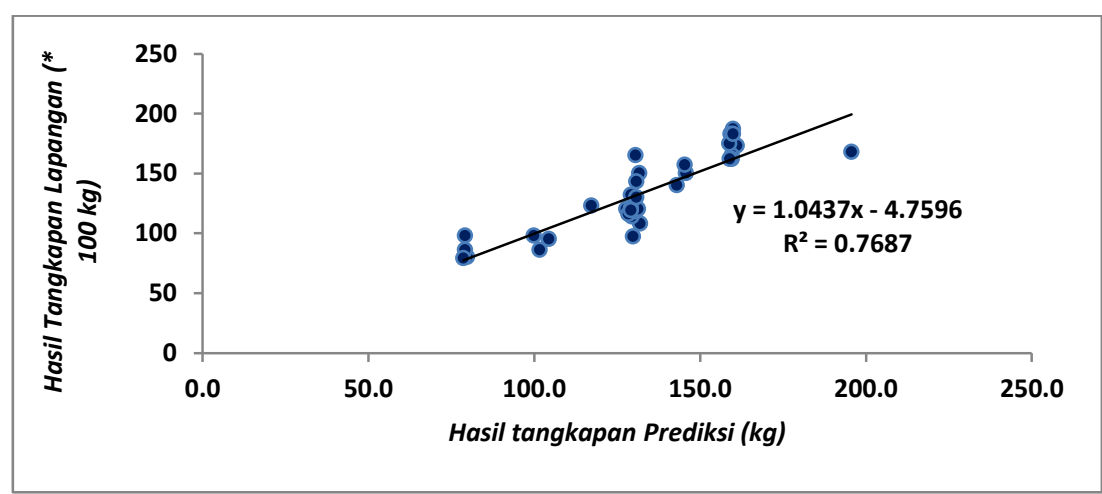

Gambar 3. Hubungan Hasil Tangkapan Lapangan dan Hasil tangkapan Prediksi.

Tabel 2. Hasil Uji t Paramater Oseanografi dan Hasil Tangkapan Ikan Layang (Decapterus sp)

\begin{tabular}{|c|c|c|c|c|c|}
\hline \multirow[t]{2}{*}{ Model } & \multicolumn{2}{|c|}{$\begin{array}{c}\text { Unstandardized } \\
\text { Coefficient }\end{array}$} & \multirow{2}{*}{$\begin{array}{c}\text { Standardized } \\
\text { Coefficient }\end{array}$} & \multirow[t]{2}{*}{$\mathrm{T}$} & \multirow[t]{2}{*}{ Sig. } \\
\hline & B & Std. Error & & & \\
\hline Constant & 9.025 & 11.476 & & 0.786 & 0.438 \\
\hline SPL & -3.625 & 7.801 & -0.42 & -0.465 & 0.645 \\
\hline Klorofil-a & -2.284 & 0.240 & -.868 & -9.514 & 0.000 \\
\hline
\end{tabular}

Beberapa jenis hama yang ditemukan di lapangan dan menyebabkan kerusakan pada daun Meranti di areal pesemaian PT. Gema Hutani Lestari diantaranya yaitu: Kumbang Puthul (Holotrichia helleri), Ulat Penggulung Daun (Lamprosema indicara), dan Belalang (Dissostura SP).

\subsection{Aplikasi SIG Untuk Pemetaan Distribusi Ikan Layang (Decapterus sp) di Perairan Pesisir Ternate}

Kondisi parameter oseanografi suatu perairan akan berpengaruh terhadap distribusi suatu spesies ikan. Perubahan parameter oseanografi akan memberikan dampak kepada sumberdaya diantaranya spesies ikan akan menghindar dan akan terdistribusi sesuai dengan kondisi lingkungan serta berdasarkan aktivitas yang dilakukan. Secara umum spesies ikan akan memilih habitat yang lebih sesuai dengan kondisi oseanografi perairan, sehingga distribusi spesies ikan sangat selalu dipengruhi oleh parameter oseanografi perairan.

\subsubsection{Suhu Permukaan Laut}

Hasil pengukuran suhu permukaan laut selama penelitian berkisar antara $30.03-30.50$ ${ }^{\circ} \mathrm{C}$, dengan rata-rata suhu permukaan laut (SPL) adalah $30.18{ }^{\circ} \mathrm{C}$. Sebaran frekuensi hasil tangkapan ikan layang (Decapterus sp) dan suhu permukaan laut (Gambar 8) sedangkan Peta sebaran suhu permukaan laut dengan hasil 
tangkapan ikan Layang dapat dilihat pada Gambar 4.

Gambar 4, menunjukan sebarang hasil tangkapan ikan Layang terkonsentrasi pada sebaran suhu $30.03-30.50{ }^{\circ} \mathrm{C}$, dengan frekuensi hasil tangkapan tertinggi terdapat pada kisaran suhu $30.03-30.19{ }^{\circ} \mathrm{C}$ yaitu $60.14 \%$ sedangkan frekuensi tangkapan terendah terdapat pada kisaran $30.44-30.50{ }^{\circ} \mathrm{C}$ dengan frekuensi hasil tangkapan $2.18 \%$. Grafik pada Gambar 4 terlihat bahwa ada kecenderungan penurunan frekuensi hasil tangkapan seiring dengan kenaikan suhu permukaan laut (SPL) hal ini dikarekana kisaran suhu permukaan laut (SPL) selama penelitian merupakan kisaran suhu yang lebih tinggi dari kisaran suhu yang disukai oleh ikan layang, ini sesuai dengan hasil penelitian Suhartono $d k k$ (2013) di Kab. Pangkep, hasil tangkapan ikan Layang (Decapterus sp) paling banyak pada kisaran suhu $29.193-30.045{ }^{\circ} \mathrm{C}$. Peta sebaran hasil

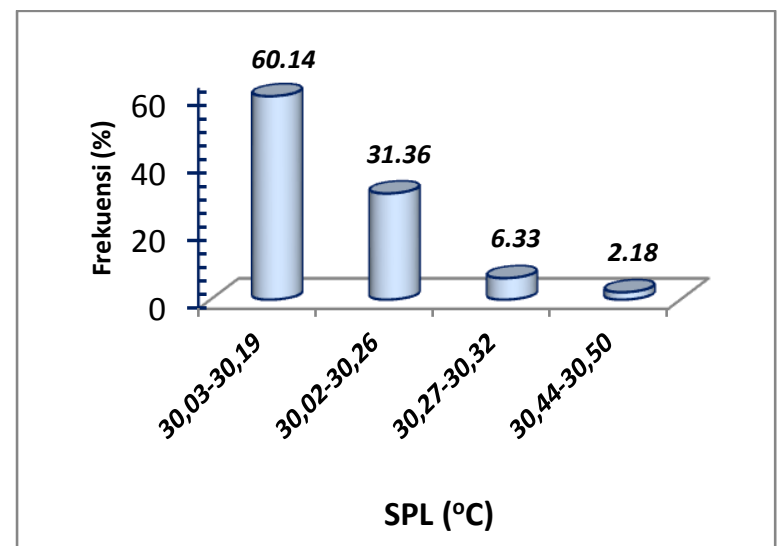

Gambar 4. Grafik Frekunesi Tertangkapnya Ikan Layang (Decapterus sp) Berdasarkan SPL

\subsubsection{Klorofil-a}

Klorifil-a biasa atau disebut dengan figmen photosintetik dari plankton merupakan salah satu komponen biologi laut yang penting terutama untuk menentukan potensi sumberdaya perikanan serta populasi dapat berubah dari tahun ke tahun terkait dengan perubahan iklim musiman dan tahunan (Hendiarti, 2008). Hasil uji $t$ dilihat bahwa secara individu klorofil-a berpengaruh nyata terhadap hasil tangkapan ikan layang (Decapterus sp) dengan nilai signifikansi $0.000<$ lebih kecil dari 0.1 . tangkapan dengan suhu pernukaan laut (Gambar 5) menunjukan kisaran suhu pemukaan laut selama penelitian mengalami fluktuasi dengan ranges yang kecil, dimana suhu terendah adalah $29.3{ }^{\circ} \mathrm{C}$ dan tertinggi adalah $32.474{ }^{\circ} \mathrm{C}$, kecilnya fluktuasi suhu permukaan laut menyebabkan hasil $t \mathbf{~} 0.645>$ 0.1) atau secara individu suhu permukaan laut tidak berpengaruh nyata terhadap hasil tangkapan ikan layang (Decapterus sp).

Kecil fluktuasi suhu ini disebabkan karena radiasi sinar matahari yang tidak mengalami perubahan yang besar atau relatif hampir sama setiap hari pada saat pengambilan sampel yang dilakukan pada musim barat. Menurut Reddy (1993), suhu pada permukaan lapisan permukaan adalah seragam karena percampuran oleh angin dan gelombang sehingga lapisan ini dinamakan lapisan percampuran (mixed layer).

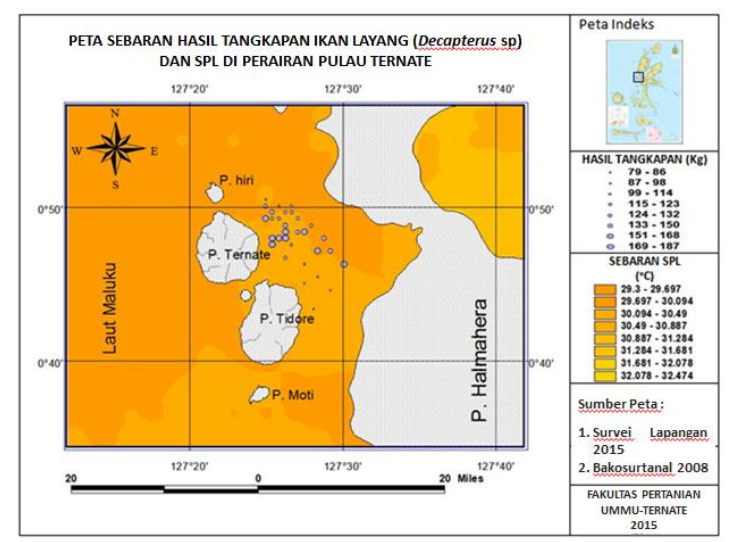

Gambar 5. Peta Sebaran Hasil Tangkapan Ikan Layang (Decapterus sp) dengan SPL

Gambar 7 memperlihatkan peta sebaran klorofil-a dan hasil tangkapan ikan layang (Decapterus sp), dimana secara umum dilihat bahwa sebaran klorofil-a di perairan laut Ternate berkisar antara $0.007-0.517 \mathrm{mg} / \mathrm{m}^{3}$. hasil tangkapan ikan Layang (Decapterus sp) terdistribusi kisaran klorofil-a $0.17-0.25 \mathrm{mg} / \mathrm{m}^{3}$ ini menunjukan bahwa secara keseluruhan perairan laut pulau Ternate merupakan daerah dengan produktivitas yang cukup baik sebagai daerah penangkapan ikan layang (Decapterus sp) sesuai dengan pendapat Gower (1972) bahwa konsentrasi klorofil-a diatas $0.2 \mathrm{mg} / \mathrm{m}^{3}$ dapat mengindikasikan keberadaan plankton 
yang cukup untuk menjaga kelangsungan hidup ikan. Hasil penelitian Isnawati (2008) diperairan Kabupaten Pangkep menemukan bahwa hasil tangkapan ikan layang tertinggi berada pada kisaran $0.2-0.4 \mathrm{mg} / \mathrm{m}^{3}$. Nilai ratarata konsentrasi klorofil-a pada musim barat $\mathrm{di}$

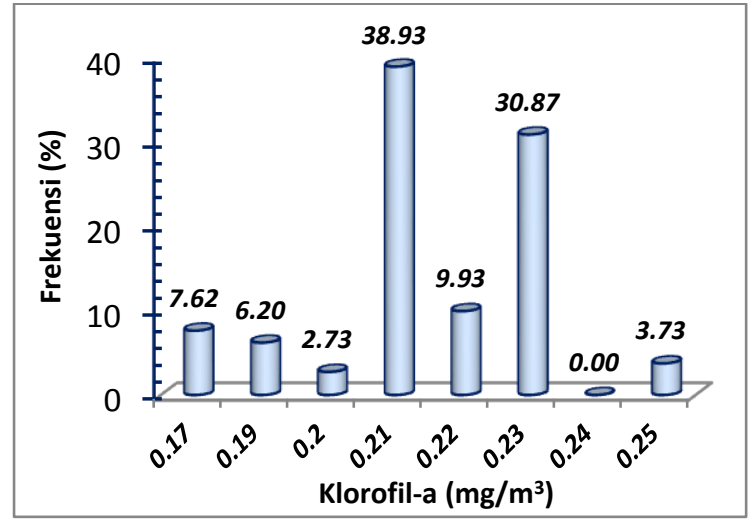

Gambar 6. Grafik Frekunesi Tertangkapnya Ikan Layang (Decapterus sp) Berdasarkan Klorofil-a

\subsubsection{Prediksi Daerah Potensial Penangkapan} Ikan Layang (Decapterus sp)

Berdasarkan hasil analisis terhadap indikator daerah penangkapan potensial seperti suhu permukaan laut, klorofil-a optimum dan jumlah produksi hasil tangkapan ikan layang, maka prediski daerah penangkapan ikan layang selama musim peralihan I (Maret - Mei 2015) yang terdapat di pesisir perairan pulau Ternate dibagi atas tiga kategori, yaitu daerah penangkapan ikan sedang terdapat pada koordinat 0053'3.03" N, 127024'50.41" E. Daerah penangkapan ikan yang baik terdapat pada

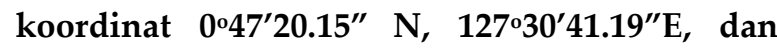
daerah penangkapan ikan yang potensial terdapat pada $0^{\circ} 50^{\prime} 14.0^{\prime \prime} \mathrm{N}, 1^{127^{\circ} 25^{\prime} 15^{\prime \prime}} \mathrm{E}$. Prediski daerah penangkapan ikan layang di perairan pulau Ternate dapat dilihat pada Gambar 8.

\section{PENUTUP}

\subsection{Kesimpulan}

Hasil penelitian menunjukan bahwa :

1. Secara bersama-sama suhu permukaan laut dan klorofil-a berpengaruh nyata terhadap perairan pulau Ternate adalah $0.21 \mathrm{mg} / \mathrm{m}^{3}$, nilai ini sesuai dengan pendapat Nontji (2002) bahwa nilai rata-rata klorofil-a diperairan Indonesia selama musim barat adalah 0,24 $\mathrm{mg} / \mathrm{m}^{3}$.

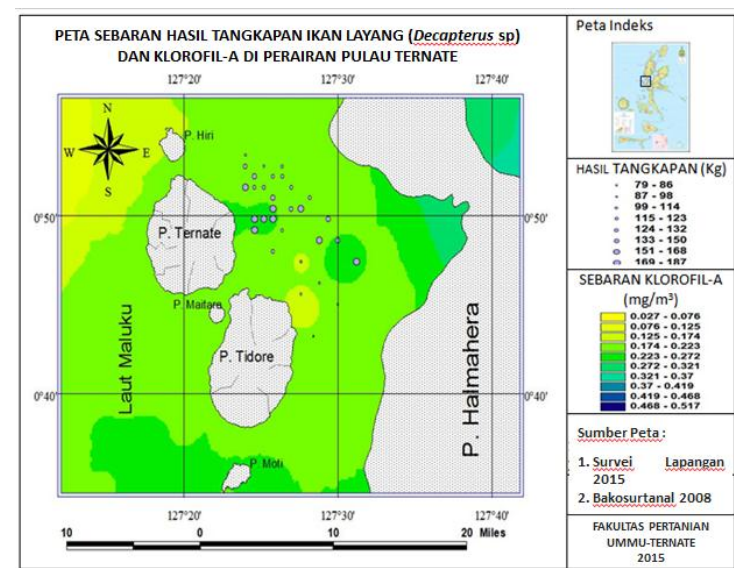

Gambar 7. Peta Sebaran Hasil Tangkapan Ikan Layang (Decapterus sp) dengan Klorofil-a

hasil tangkapan ikan di pesisir pulau Ternate, sedangan hasil uji $t$ menunjukan bahwa secara individu parameter klorofil-a yang berpengaruh nyata terhadap hasil tangkapan ikan laying (Decapterus sp).

2. Prediksi daerah penangkapan yang potensial penangkapan ikan laying di perairan laut pulau Ternate terdapat pada bagian timur pulau ternate dengan koordinat $0^{\circ} 50^{\prime} 14.0^{\prime \prime} \mathrm{N}, 127^{\circ} 25^{\prime} 15^{\prime \prime} \mathrm{E}$.

\subsection{Saran}

Mengacu pada keterbatasan selama penelitian dilaksanakan, maka penulis menyarankan perlu dilakukan validasi data daerah penangkapan potensial ikan yang dihasilkan dengan menggunakan data penginderaan jauh dan data lapangan, selanjutnya perlu dilakukan penelitian lanjut terhadap parameter oseanografi lainnya setiap musim sehingga dapat menghasilkan data yang benar-benar valid dan dapat digunakan oleh nelayan dalam melakukan proses penangkapan. 

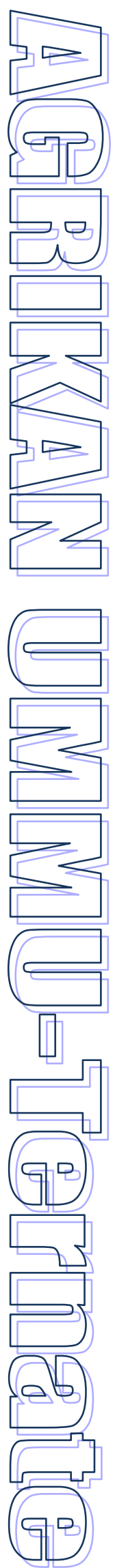

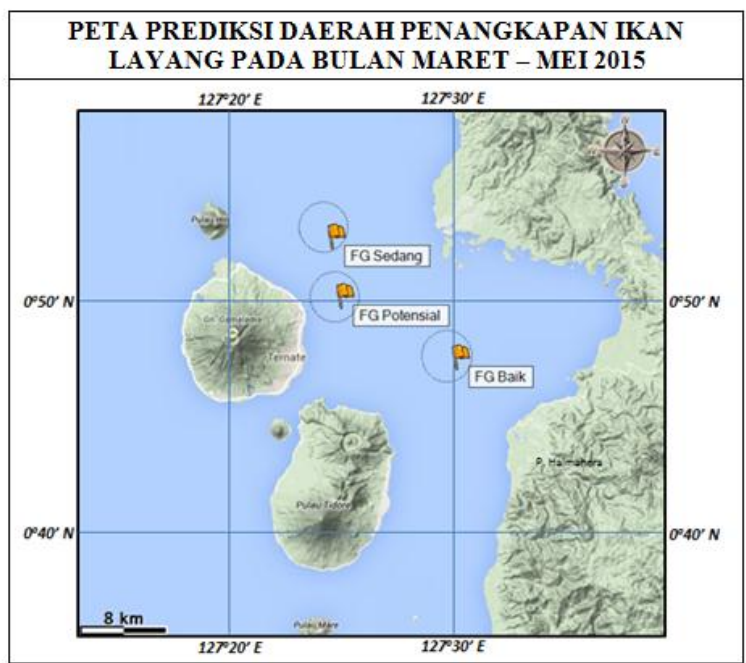

Gambar 8. Peta Prediksi Daerah Penangkapan Ikan Layang pada bulan Maret - Mei 2015 di Pesisir Pulau Ternate

\section{DAFTAR PUSTAKA}

Dinas Perikanan dan Kelautan Kota Ternate., 2011. Statistik Perikanan Tangkap. Laporan Tahunan. DKP-Kota Ternate.

Gazali, I dan Manan, A., 2012. Prakiraan Daerah Penangkapan Ikan Di Selat Bali Berdasarkan Data Citra Satelit. Jurnal Ilmiah Perikanan dan Kelautan Vol. 4 No. 1. 87-91.

Gunarso, W. 1985. Tingkah Laku Ikan: Hubungannya Dengan Alat, Metode dan Taktik Penangkapan. Jurusan Pemanfaatan Sumberdaya Perikanan. Fakultas Perikanan. Institut Pertanian Bogor. Bogor.

Laevastu, T., And Hayes, M.L. 1981. Fiheries Oseanography and Echology. Fishing News Book. London.

Nontji A., 2002. Laut Nusantara. Djambatan. Jakarta.

Nybaken, J. W. 1982. Biologi Laut : Suatu Pendekatan Ekologis. PT. Gramedia. Jakarta.

Rasyid, J, Abd., 2010. Distribusi Suhu Permukaan Pada Musim Peralihan Barat-Timur Terkait Dengan Fishing Ground Ikan Pelagis Kecil Di Perairan Spermonde. Jurnal Torani (Jurnal Ilmu Kelautan dan Perikanan) Vol. 20 (1) April 2010: 1- 7. ISSN: 0853-4489

Reddy MP. 1993. Influence of the Various Oceanographic Parameters on the Abundance of Fish Catch. Proceeding of International Workshop on Application of Satellite Remote Sensing for Identifying and Forecasting Potential Fishing Zones in Developing Countries. India, 7-11 December 1993.

Safruddin, 2013. Distribusi Ikan Layang (Decapterus Sp) Hubungannya Dengan Kondisi Oseanografi Di Perairan Kabupaten Pangkep, Sulawesi Selatan. Jurnal Torani Vol. 23 (3) Des 2013, Hal 150-156. ISSN: 0853-4489.

Zainuddin, M. 2006. Predicting potential habitat hot spots for albacore tuna and Migration Pattern for Albacore Tuna, Thunnus alalunga, in the Northwestern North Pacific using Satellite Remote Sensing and GIS. Ph.D Dissertation. Hokkaido University. 108pp.

Widodo, J. Dan Suadi. 2006. Pengelolaan Sumberdaya Perikanan Laut. Gadjah Mada University Press. Yogyakarta.

Hendiarti N., 2008. Hubungan Antara Keberadaan Ikan Pelagis Dengan Fenomena Oseanografi Dan Perubahan Iklim Musiman Berdasarkan Analisis Data Penginderaan Jauh. Globe Vol 10, 19 , dan 25. 